\title{
IMPLEMENTASI PENDEKATAN HOTS (HIGHER ORDER THINKING SKILLS) DALAM PEMBELAJARAN PAI
}

\author{
(Studi Pada Siswa Kelas X Di SMAN 2 Pasuruan Jawa Timur) \\ Siti Halimah
}

STIT PGRI Pasuruan, Indonesia

Corresponding author: halimahsiha@gmail.com

Submission Track:

Submisson $\quad: 12-08-2021$

Accept Submission : 07-09-2021

Avaliable Online : :11-09-2021

Copyright @ 2021 Author

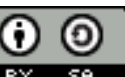

This work is licensed under a Creative Commons Attribution-ShareAlike 4.0

\begin{abstract}
The research's context is that is new challenges for teachers in facing Era 5.0, the teachers must be to make new breakthroughs in designing innovative and interesting active learning. As educators in the era of society 5.0, teachers must have digital skills and creative thinking. Educators are also required must be to create innovative learning and dinamic. To realize the implementation of innovative and dynamic learning, one can implement a learning approach that can improve skills of critical thinking as name is the Higher Order Thinking Skills (HOTS) approach. The aims of this reseach is to discribe that in developing students' skillis of critical thinking in Islamic religious education (PAI) subjects, that is necessary to implement learning with the Higher Order Thinking Skills (HOTS) approach. This study is using the methods of qualitative method and that approach is used approach of descriptive. The locus of this study at SMAN 2 Pasuruan. That point data sources of the study are PAI teachers, students of $X$ Bahasa, X IPS I and X MIPA I and the principal. The sources of others Data are books, journals, studi result and document as a previous research, documents for class $X$ quiz questions, photos and audio. The Collection Data used the techniques of observation, interview, and documentation. The analysis data is used The technique of qualitative. The studi is outcoming about the implementation of the HOTS approach in PAI learning can be doing strat from making lesson plans, then implementing PAl learning by applying the HOTS approach and at the end of the learning implementation an evaluation is carried
\end{abstract}


out to find out the results of the implementation of this HOTS approach. From the findings in the application of PAl learning using the HOTS approach, it is mapped into 3 parts, namely, the initial part, namely the teacher analyzing the learning method that will be used and the results can be concluded that class $X$ students of SMA Negeri 2 Pasuruan have been able to improve their critical thinking skills, they can also solve problems such as in the topic of Behavioral Discipline. At the next stage, the teacher must evaluate to the method has aplicated in the class, for example, the PAl teacher gives negative statements that need to be corrected by students, then students describe ideas and input about these statements, for example, Discipline Attitudes and Attitudes Competing in doing good. In the final stage, the teacher manifests seeing the transformation of the behavior of Class $X$ students after receiving PAl lessons.

Keywords: HOTS Approach, Islamic Education Learning, Think Critical

\begin{abstract}
Abstrak
Latar belakang penelitian ini adanya tantangan baru bagi guru dalam menghadapi Era 5.0, guru dituntut dapat membuat trobosan-trobosan baru dalam mendesain pembelajaran yang aktif inovatif dan menarik. Sebagai Tenaga Pendidik di era society 5.0, maka adanya guru harus memiliki digital's skills dan creative thinking. Tenaga pendidik juga diharuskan mampu menciptakan pembalajaran yang inovatif dan dinamis. Untuk mewujudkan pelaksanaan pembelajaran yang inovatid dan dinamis dapat mengimplementasikan pendekatan pembelajaran yang dapat meningkatkan kemampuan berpikir kritis disebut pendekatan Higher Order Thinking Skills (HOTS). Tulisan ini menyajikan tentang sebuah teknik yang dapat digunakan oleh guru dalam upaya mengasah dan meningkatkan Critical Thinking Skills siswa pada mata pelajaran PAl ini dapat memanfaatkan pendekatan Higher Order Thinking Skills (HOTS) dalam kegiatan pembelajaran. Adapun penggunaan metode dalam penelitian ini menggunakan metode kualitatif dan pendekatan yang digunakan adalah deskriptif kualitatif. Lokasi pengambilan data dalam penelitian ini berada di SMAN 2 Pasuruan. Pengambilan data ini diambil dari sumber data kunci yaitu Guru Pendidikan Agama Islam, para siswa Kelas $X$ Bahasa, X IPS I dan X MIPA 1 dan juga kepala sekolah. Penelitian ini juga didukung dengan adanya sumber data tambahan yang dihasilkan dari beberapa buku, ebook, Jurnal Publikasi dan juga hasil dan dokumentasi. Data dokumentasi berupa arsip Rencana Pelaksanaan Pembelajaran, arsip Soal Quis untuk kelas $X$ beberapa foto dan audio pembelajaran. Dalam pengumpulan data penelitian ini, peneliti memanfaatkan teknik pengamatan lapangan, interview dengan sumber data, serta mengumpulkan arsip-arsip yang dapat menjadi data dalam penelitian ini. Untuk mengalasis hasil penelitian ini, peneliti mengguunak teknik analisis data kualitatif deskriptif. Temuan penelitian dapat menunjukkan bahwa Implementasi Pendekatan HOTS dalam pembelajaran PAI tersebut, pelasanaannya dapat dilakukan melalui merencanakan dengan membuat RPP, lalu melaksanakan pembelajaran PAI dengan menerapkan Pendekatan HOTS dan di akhir pelaksanaan pembelajaran dilakukan evaluasi untuk mengetahui hasil dari implementasi pendekatan HOTS ini. Dari hasil temuan dalam penerapan pembelajaran PAI menggunakan pendekatan HOTS ini dipetakan
\end{abstract}


menjadi 3 bagian yaitu, bagian awal yakni Guru melakukan analisis terhadap metode pembelajaran yang akan digunakan dan hasilnya dapat disimpulkan bahwa siswa kelas X SMAN 2 Pasuruan telah mampu meningkatkan kemampuan berfikirnya secara kritis, mereka juga dapat menyelesaikan masalah seperti dalam topik berprilaku Disiplin. Pada tahapan selanjutnya Guru melaksanakan evaluasi terhadap penerapan metode yang digunakan dalam Proses belajar mengajar, seperti contoh guru PAI memberikan pernyataan negatif yang perlu dikoreksi oleh siswa, kemudian siswa mendeskripsikan ide-ide dan masukan tentang pernyataan tersebut misal materi Sikap Disiplin dan Sikap Berlomba-lomba dalam berbuat kebaikan. Di tahap akhir, Guru melakukan manifestasi melihat transformasi perilaku siswa-siswa Kelas $X$ sesudah menerima pelajaran PAI.

Kata kunci: Pendekatan HOTS, Mata Pelajaran PAI, Critical Think Skills

\section{PENDAHULUAN}

Sekarang ini, kita sedang berada pada fourth Revolution Era dikenal dengan Era Revolusi Industry 4.0. Dalam kawasan pendidikan disebut dengan "Era Pendidikan 4.0" yang mana pada masa ini memunculkan ancaman bagi para pendidik. Salah satu ancaman pendidikan masa 4.0 ini dipaparkan oleh Menteri Pendidikan dan Kebudayaan bahwa guru harus menjadi tenaga penggerak dalam memajukan Indonesia sehingga guru harus mampu mencetak generasi yang unggul di masa mendatang (Direktorrat Jenderal Guru dan Tenaga Kependidikan, 2019).

Guru harus mengutamakan kepentingan peserta didik di atas kepentingan pribadinya, mampu memprakarsai dalam melakukan perubahan pada peserta didiknya, secara cekatan dalam melakukan tindakan secara cepat dan tepat tanpa diperintah, mampu melakukan trobosan-trobosan baru yang dapat mendesain pembelajaran yang menarik, berinovasi dan aktif.

Pengaruh dari munculnya Revolusi Industri 4.0 ini belum usai lantas secara bersamaan lahirlah era Society 5.0, tanpa kita menyadari bahwa sekarang ini pendidikan telah memasuki para Era Pendidikan 5.0, pada masa revolusy ini mendorong masyarakat harus berpusat pada keseimbangan. Pada awalnya Interner berfungsi sebagai sarana Informasi namun pada saat ini internet dijadikan sebagai sarana dalam menjalani kehidupan sehar-hari. Sebagian manusia menjadikan teknologi sebagai bagian dari hidupnya, semakin melesat kehadiran teknologi dapat mengurangi adanya ketakseimbangan manusia dan juga dapat memunculkan permasalahan baru dikemudian hari.

Societi 5.0 adalah kehidupan manusia dalam bermasyarakat yang semuanya bermuara pada teknologi dalam pencarian solusi terhadap ancaman dan problem sosial menggunakan berbagai inovasi yang lahir di masa Revolusi industri 4.0 sepertipemanfaatan internet dalam segala hal, memodifikasi kecerdasan, pembuatan Data dalam Kapasitas besar, dan mendesain mesin untuk menciptakan kehidupan manusia lebih ungggul dan berkualitas. Sebagai Tenaga Pendidik di masa 5.0, maka adanya guru harus memiliki digital's skills dan creative 
thinking. Tenaga pendidik juga diharuskan mampu menciptakan pembalajaran yang inovatif dan dinamis (Thufail FI, 2011).

World Economic Forum memberikan rumusan tentang skill yang harus dipersiapkan untuk menyongsong Masyarakat yang super pintar itu. Skill yang paling utama yang harus dipersiapkan yaitu cara berfikir tingkat tingggi, dalam hal ini menjadi keharusan bagi kalangan pendidikan. Cara berpikir analitis, objektif, dan inovatif itulah yang disebut HOTS atau Higher Order Thinking Skills. HOTS ini merupakan cara berpikir secara kompleks, berjenjang, dan sistematis.

High Order Thinking Skills (HOTS) adalah sebuah sistem berfikir dengan cara menghafal dan mendiskripsikan kembali pengetahuan yang sudah diperoleh. Skill paling tinggi ini yakni sebuah skill yang dapat mengkaitkan, merubah, memodifikasi ilmu pengetahuan dengan keahlian yang sudah didapatkan supaya berguna untuk memilih alternatif solusi dalam menyelesaikan permasalahan pada suatu kondisi tertentu.

Untuk mewujudkan anak didik yang bermanfaat, berkreasi dan berinovasi makan dapat dilakukan dengan cara menuangkan dalam kegiatan belajar mengajar dengan menggunakan sebuah pendekatan yang dapat meningkatkan Skill berfikir kritis siswa, pendekatan ini disebut sebagai pendekatan Higher Order Thinking Skills (HOTS). Pendekatan ini adalah sebuah pendekatan yang menyatukan antara keahlian merubah dan memodifikasi pengetahuan dan pengalaman yang telah ada dalam setiap peserta didik (Rofiah dkk, 2013). Pendekatan HOTS ini banyak dimanfaatkan dalam pembelajaran ilmu pengetahuan alam sebagaimana dalam hasil temuan penelitian oleh Putri Nugraheni Wijayanti, dalam penelitian Putri lebih menekankan terhadap pembelajaran tematik yang berbasis HOTS. Namun, penerapan pendekatan ini juga relevan dan efektif jika diterapkan dalam mata pelajaran lainnya seperti dalam mata pelajaran Pendidikan Agama Islam (PAI)

Membahas tentang hal di atas, pemanfaatan pendekatan ini dalam mata pelajaran PAl pada tingkatan Sekolah Menengah Atas memprioritaskan pada kemampuan menalar. Dengan harapan peserta didik memiliki skill berfikir kritis dan analitis tentang materi keagamaan yang mudah dipraktikkan dalam kegiatan harian. Pembelajaran PAl tingkatan Belajar Menengah Atas dan setaranya diharapakan mampu memunculkan pengetahuan yang berkaitan terhadap peristiwa yang terjadi saat ini. Bersamaan dengan kecanggihan IPTEK sekarang ini bisa memunculkan Isu SARA tentang agama yang dapat memicu konflik. Kemudahan bagi masyarakat dalam mengakses berita, pengetahuan dan informasi dapat memanifestasikan munculnya pengetahuan, pengalam dan pemikiran yang baru, hal ini dapat memicu timbulnya perbedaan pendapat dan konflik baru di kalangan masyarakat. Sebab itu, maka peserta didik tingkatan Sekolah Menengah Atas diupayakan memiliki kemampuan perfikir tingkat tinggi, khususnya dalam mempelajarai pelajaran Agama Islam. Berdasarkan tujuan supaya peserta didik mampu menyelesaikan konflik agama yang terjadi di lingkungan masyarakat secara bijak dan tidak terpengaruh dengan beritaberita hoax yang mana sumber beritanya tidak credible.

Seperti hasil studi observasi pendahuluan oleh penulis terhadap guru PAI 
bahwa antusiasme dan minat belajar siswa ini semakin menurun terhadap pembelajaran, namun setelah adanya perubahan kurikulum K-13 yang mana adanya kurikulum ini menuntut para guru untuk mampu menerapkan pendekatan saintifik dengan pembelajaran inovatif yang dapat menciptakan antusiasme belajar secara aktif dan kreatif sehingga Guru PAI mencoba trobosan baru dengan mendesain pembelajaran PAI dengan menggunakan pendekatan HOTS ini. SMAN 2 Pasuruan ini merupakan sekolah Negeri di Kota pasuruan yang telah menerapka kurikulum 13 dan sekolah terpilih menjadi lokasi percobaan penerapan Kurikulum 2013 dengan memanfaatkan pendekatan saintifik dalam kegiatan belajar mengajarnya. Melalui penelusuran penulis terhadap penelitian terdahulu, penulis belum menemukan penelitian sejenis yang membahas tentang penerapan Pendekatan saintifik model HOTS dalam pembelajaran PAI. Dari hasil studi pendahuluan ini, peneliti berasumsi bahwa impelementasi pendekatan HOTS dalam pembelajaran PAI ini mampu meningkatkan antusiasme dan minat belajar siswa.

Meninjau data empiris yang telah dipaparkan di atas. Sebuah upaya untuk menciptakan siswa yang aktif, kreatif dan inovatif maka diperlukan untuk mendesain pembelajaran PAI yang dapat meningkatkan kemampuan berfikir kritis siswa yang disebut PENDEKATAN HOTS (HIGHER ORDER THINKING SKILLS). Demikian ini merupakan kajian yang sangat penting untuk ditelusuri bagaimana bentuk dari implementasi pendekatan ini dilaksanakan dengan harapan dapat berguna dan bermanfaat untuk meningkatkan mutu pembelajaran PAI.

\section{METODE PENELITIAN}

Dalam tulisan ini, penulis memanfaatkan metode kualitatif dengan pendekatan deskriptif kualitatif dikarenakan pada penelitian ini ingin menjelaskan dan menafsirkan gejala, fonomena, peristiwa individu maupun kelompok tertentu (Moloeng, 2002). Penggunaan metode tersebut, peneliti memperoleh dan mendalami data di lokasi secara lengkap dan detail dengan cara melakukan interview, pengamatan di lokasi penelitian, dan dokumentasi yang bisa diambil sebagai data penelitian. Metode kualitatif dapat mendiskripsikan data-data tentang hal-hal yang dilakukan, dirasakan dan dialami (Sugiyono, 2013) dalam penerapan pendekatan HOTS dalam pembelajaran PAI pada siswa SMA Negeri II Kota Pasuruan.

Penelitian ini dilakukan di SMAN 2 Pasuruan. Adapun dalam penentuan sumber informasi peneliti menggunakan teknik Purposive Sampling. sumber informasi dalam studi ini adalah kepala sekolah, Waka Kurirukulum, guru PAI 3 orang, siswa kelas X BHS berjumlah 20 Siswa, kelas X IPS I sejumlah 12 siswa, kelas X MIPA I sejumlah 19 siswa, dan guru PAI merupakan sumber informasi yang paling inti dan utama. Dalam penelitian ini menggunakan metode analisis data yang bersifat induktif dan diperkuat data kualitatif. Tahapan dalam melakukan analisi data menggunakan 3 tahapan yaitu, reduksi data penyajian data, penarikan kesimpulan (Arikunto, 2002). 


\section{PEMBAHASAN DAN HASIL PENELITIAN}

\section{Definisi HOTS (HIGHER ORDER THINKING SKILLS)}

HOTS (Higher Order Thingking Skill) atau yang sering disebut sebagai kemampuan keterampilan atau konsep berpikir tingkat tinggi merupakan suatu konsep reformasi pendidikan berdasarkan pada taksonomi bloom yang dimulai pada awal abad ke-21. Konsep ini dimaksukan ke dalam pendidikan bertujuan untuk mempersiapkan SDM unggul yang siap menyongsong revolusi industri. Dalam abad 21 ini SDM memiliki keterampilan dan keahlian. Menurut Abduhzen. HOTS ini merupakan sebuah sasaran terakhir dalam pembelajaran yang berbentuk sebuah pendekatan pembelajaran ( Sofyan, 2019).

Menurut Thomas \& Thorne, Higher Order Thingking Skill adalah cara berpikir lebih tinggi dari sekedar menghafalkan fakta, menjelaskan fakta, atau menerapkan peraturan, rumus, dan prosedur". Pendapat ini sependapat dengan Onosko \& Newman, Higher Order Thingking Skill dapat diartikan sebagai potensi penggunaan pikiran untuk menghadapi tantangan baru yang belum pernah dipikirkan siswa sebelumnya" (Nugroho, 2018). Menurut Under bakke, "Higher Order Thingking Skill juga disebut kemampuan berpikir strategis dalam memanfaatkan sebuah informasi untuk memecahkan permasalahan, menafsirkan argumentasi, negoisasi berita, atau membuat perkiraan" ( Sani, 2019).

Higher Order Thingking Skill merupakan pendayagunaan kognitif dalam proses berfikir yang berada dalam ingatan jangka pendek. Jika dihubungkan dengan taksonomi Bloom, proses Higher Order Thingking meliputi analisis, sintesis, dan evaluasi. Selain itu, bahwa Higher Order Thingking tersebut sangat dibutuhkan di masa kini daripada di masa-masa sebelumnya (Hayon, dkk, 2017).

Dari bebereapa pengertian diatas dapat disimpulkan bahwa HOTS (High Order Thingking Skill) adalah keterampilan berpikir tingkat tinggi yang harus ada pada diri peserta didik yang tidak hanya menguji kemampuan intelektual dalam hal ingatan tetapi juga menguji pada kemampuanmengevalusi, kreatifitas, analisis dan berpikir kritis tentang pemahaman peserta didik terhadap suatu mata pelajaran danlebih menekankan pada pemikiran-pemikiran kritis terhadap suatu penyelesaian permasalahan. Jadi disini keterampilan berpikir tingkat tinggi tidak hanya menguji pada keterampilan menghafal sebuah materi pelajaran tetapi lebih kepada penerapan. Adapun pembahasan hasil penelitian ini, sebagai berikut:

\section{Menyusun Rencana Pembelajaran PAl dengan Pendekatan HOTS}

Perencanaan pembelajaran menurut degeng "merupakan upaya guru untuk menyampai tujuan pembelajaran yang akan dilaksanakan melalui cara menyeleksi, menentukan, dan memodifikasi metode yang akan digunakan dalam proses pembelajaran" (Uno, 2016). Dan dalam merumuskan perencanaan atau yang dikenal dengan RPP (Rencana Proses Pembelajaran). 
Dalam pengembangan program pengajaran merupakan rumusanrumusan tentang tahapan-tahapan pelaksanaan proses pembelajaran. Dimana tahapan-tahapan yang dimanfaatkan dalam memperoleh tujuan belajar. Demikian ini menujukkan bahwa seorang pendidik dapat harus mendesain pembelajaran yang dengan cara melakukan perencanaan program pembelajaran secara baik.

Seperti yang dikemukakan oleh Hidayat bahwa ada beberapa hal yang perlu dipersiapkan ketika menyusun perencanaan pembelajaran antara lain: (Majid, 2017) 1). Menguasai kurikulum yang ada, 2). Menguasai bahan ajar. 3). Merencanakan sebuah program pengajaran. 4). Mengimplementasikan program pengajaran yang telah direncanakan. 5). Melakukan penilaian pada program pengajaran dan hasil pelaksanaan pembelajaran.

Jadi dari pemaparan diatas, dalam merumuskan perencanaan pembelajaran dan penilaian HOTS tidak lepas dari perencanaan RPP untuk mencapai tujuan pembelajaran dan penilaian HOTS. Dengan menggunakan RPP atau perencanaan pembelajaran bertujuan untuk sebagai pola dasar dalam mengatur tugas peserta didik, mempermudah guru dalam melaksakan proses pembelajaran, supaya dalam proses pembelajaran dan penilaian akhir saling berkaiatan.

Dalam menerapakan pendekatan HOTS ini diperlukan skill pendidik dalam menyusun perencanaan dan mendesain pembelajaran yang efektif sehingga pembelajaran yang dapat mengasah kemampuan peserta didik dalam proses berfikir secara logis, dalam bersikap maupun keterampilan lainnya. Pendidik yang profesional merupakan pendidik yang memiliki perencanaan dan pelaksanaan pembelajaran yang sistematis. Perencanaan tersebut dapat dirancang dan disusun dalam berbentuk perangkat pembelajaran. Perangkat pembelajaran adalah sebuah kunci dalam mewujudkan kesuksesan belajar karena dapat melahirkan pembelajaran yang aktif, interaktif, inspiratif, efisien, menantang, menyenangkan serta dapat mendorong motivasi peserta didik untuk berpartisipasi aktif dalam pembelajaran karena telah memfasilitasi keluasan ruang bagi kreatifitas dan kemandirian fisik serta psikologis peserta didik ( Susanto, 2016).

Adapun dalam perencanaan pembelajaran PAI yang dilakukan oleh guru PAI di SMA Negeri II Kota Pasuruan telah sesuai dengan standar penyusunan RPP. Format perencanaan yang dibuat oleh guru PAl tersebut meliputi nama mata pelajaran, kelas/semester, materi pokok, alokasi waktu, kompetensi inti, KD dan indikator pencapaian kompetensi, tujuan pembelajaran, materi pembelajaran, metode, media, sumber belajar, langkah-langkah pembelajaran terdapat kegiatan keterampilan 4C (communication. collaboration, critical thinking and problem solving, creative and innovative) dan evaluasi Observasi RPP, 2021). Dalam menyusun RPP ini guru PAl menyusun sendiri namun tetap merujuk pada sumber-sumber yang dipilih menjadi rujukan dalam penyusunan RPP. Dalam hal tujuan dan indikatoryang akan dicapai dalam pembelajaran disesuaikan dengan wawasan peserta didik dengan memperhatikan situasi siswa dan topik 
sebelumnya.

Selain perencanaan pembelajaran melalui pembuatan RPP, guru PAI juga menerapkan pembiasaan-pembiasaan sebelum pembelajaran di kelas dimulai. Guru PAI membiasakan pembacaan do'a terlebih dahulu kemudian membaca surat-surat pendek juz 30 bi attartil, dibacakan secara bersama-sama, kemudian dilanjutkan dengan penjelasan guru tentang materi dan menghubungkan dengan materi yang sudah dibahas di pertemuan sebelumnya (Wawancara Luthfi,2021). Sesuai dengan hasil wawancara dengan Angga Prasetyo bahwa sebelum kegiatana pembelajaran PAI dimulai, guru PAI biasanya memulai dengan pertanyaan-pertanyaan pendahuluan tentang materi yang akan dibahas hari ini (Wawancara Prasetyo, 2021).

Berdasarkan penjelasan sebelumnya penulis dapat memberikan kesimpulan yakni sebelum proses pembelajaran PAl dimulai guru PAI membiasakan siswanya dengan kegiatan berdo'a dan kegiatan keagamaan lainnya seperti membaca Al-qur'an surat pendek Juz 30 bertujuan untuk menyiapkan bathin siswa supaya tenang, jernih dan siap menerima pelajaran dengan baik sehingga materi yang dipaparkan oleh guru PAI mudah dimengerti dan diterima oleh siswa. Guru PAI juga sudah melaksanakan pembelajaran searah dengan isi RPP yang disusun, hal itu terbukti dari kegiatan pendahuluan yang dilakukan guru PAI dengan kegiatan berdo'a dan persepsi sebelum berlanjut pada kegiatan inti yaitu pemberian materi. Dengan langkah-langkah pelaksanaan pembelajaran yang disesuaikan dengan RPP ini dapat mempermudah guru PAI dalam mencapai tujuan pembelajaran karena RPP merupakan scenario pembelajaran, seperti yang dipaparkan oleh Kunandar (2011) menjelaskan tentang manfaat RPP yaitu menjadi rujukan bagi guru dalam menjalankan proses belajar mengajar supaya lebih terarah dan dapat terlaksana dengan efektif dan efisien. Maka dari itu, RPP yang baik adalah yang luwes dan guru memiliki wewenang untuk melakukan penyesuaian pada RPP terhadap respons siswa dalam kegiatan belajar mengajar (Kunandar, 2011).

Langkah-langkah pembelajaran Pai dengan menggunakan Pendekatan HOTS ini diawali dengan kegiatan pendahuluan: dalam kegiatan pendahuluan ini guru membuka pelajaran dilanjut pemberian apersepsi, kemudian motivasi dan dibagian akhir guru menjelaskan tentang materi apa yang akan dibahas dalam pertemuan ini. Selanjutnya masuk pada kegiatan inti. Kegiatan inti ini ada beberapa kegiatan. Kegiatan pertama yaitu kegiatan Literasi: siswa diberi dorongan dan motivasi supaya perhatian dan fokusnya bisa terpusat. Kegiatan selanjutnya Critical Thinking (berfikir Kritis), dalam kegiatan ini guru memberikan problem statemen berupa pertanyaan/identifikasi masalah dan akan dijawab melalui kegiatan belajar. Selanjutnya kegiatan koleksi data: pada kegiatan ini siswa diperintahkan untuk mencari dan membaca sumber belajar bisa dari buku, jurnal dan juga dari internet. Selanjutnya kegiatan Kerja Sama: dalam kegiatan ini siswa diperintah untuk berkelompok dan melakukan diskusi dalam kelompok tentang problem statemen yang diberikan guru. Selanjutnya kegiatan 
Verifikasi/pembuktian: pada tahap ini siswa memverifikasi tentang ide yang ditawarkan dengan teori yang ada dalam sumber-sumber yang sudah dibaca. Kegiatan selanjutnya komunikasi: siswa menjelaskan hasil diskusi kelompok dengan perwakilan kelompok maju ke depan kelas. Kegiatan terakhir yaitu kegiatan penutup: pada kegiatan ini, guru menugaskan kepada siswa untuk membuat rangkuman materi yang telah dipelajari hari ini, kemudian guru memeriksa hasil kerja siswa, guru memberikan penekanan dengan menyimpulkan materi hari ini, kemudian guru menanyakan tingkat pemahaman siswa tentang materi yang sudah dipelajari selanjutnya guru menutup pertemuan.

\section{Pelaksanaan Pembelajaran PAI dengan Pendekatan HOTS}

HOTS dalam pembelajaran bukan berperan sebagai sebuah metode pembelajaran tetapi HOTS disini dimaksudkan pembelajaran yang mampu menyiptakan peserta didik untuk berpikir HOTS seperti kemampuan memahai, menganalisis, mengevaluasi, menciptakan, mengidentifikasi suatu pelajaran atau soal-soal dalam pembelajaran.

Sebelum melaksanakan pembelajaran yang berbasis HOTS disini guru juga harus menguasai dan faham tentang pembelajaran HOTS itu seperti apa. Guru juga harus mendesain dan mempunyai gambaran metode yang cocok untuk menerapkan pendekatan HOTS disesuaikan dengan siswa yang akan dihadapi sehingga pembelajaran dapat terlaksana secara maksimal dalam mencapai tujuan pembelajaran. Dengan begini siswa akan terbiasa berfikir HOTS (Nugroho, 2018 ). Semua siswa harus berpikir aktif dalam melaksanakan proses belajar dan diharapkan peran siswa lebih dominan daripada pendidik. pendidik hanya sebagai fasilitator untuk mempermudah dalam mengarahkan jalannya proses pembelajaran dengan begini siswa lebih mudah dalam mengembangakan keterampilan berpikir kreatif, inovatif, aktif sinkron dengan proses belajar yang didesain oleh pendidik. Pendidik membuka kesempatan yang luas kepada siswa untuk mencari, merumuskan dan menemukan sendiri apa saja yang akan dipelajarinya. Sebelumnya guru juga harus menyiapkan tugas- tugas atau soal permasalahan yang dapat mempertajam keterampilan peserta didik dalam berpikir kreatif, kritis, dan menyelesaikan masalah (Sani, 2019).

Secara teoritis menurut Brookharth HOTS merupakan bagian utama dalam proses belajar mengajar yang harus dikembangkan. Tujuan pembelajaran dengan pendekatan HOTS adalah untuk memberi bekal kepada siswa supaya memiliki keterampilan dalam beragumentasi dan mengambil sebuah keputusan. Dari hasil penelitian Murray, memaparkan bahwa dalam pembelajaran yang menggunakan pendekatan HOTS ini dikatakan siswa mampu mengambil keputusan tentang apa yang akan ia percaya dan tentang hal apa yang akan ia laksanakan, mampu memunculkan gagasan-gagasan baru, membuat estimasiestimasi dalam menyelesaikan permasalahan (Susanto dan rahmawati, 2016).

HOTS merupakan pembelajaran yang menjadikan informasi dan ide 
dengan cara mengubah makna dan implikasinya. Hal ini seperti ketika pembelajaran menggabungkan fakta dan gagasan kemudian memberi sintesi, melakukan generalisai, memaparkan, memberikan kesimpulan. Maka dari itu, peserta didik harus bisa memahami, menafsirkan, menganalisis, serta menginterprestasi informasi yang diterima dalam pembelajaran. HOTS juga menuntut peserta didik untuk berpikir kritis dalam mengkaji informasi, membuat simpulan, serta membuat generalisasi. Dalam Taksonomi Bloom revisi, HOTS merupakan kemampuan kognitif pada tingkat penerapan, analisis, evaluasi, dan inovasi.

Pembalajaran HOTS biasanya berkarakteristik dengan pembelajaran abad 21 karena di era globalisasi atau era informasi telah adanya proses perubahan antar negara, antar bangsa, antar budaya, tanpa mengenal batas. Hidayat rais dan Yuyun Elizabeth menyatakan bahwa pendidikan diabad 21 harus menjadi pondasi utama dan tempat bersemainya kebaikan untuk mentrasformasi individu dan memperbaharui masyarakat. Oleh karena itu dibutuhkan kompetensi masa depan antara lain: kemampuan berkomunikasi, kemampuan berfikir jernih dan kritis. Senada dengan itu, Arnyana menulisakn bahwa pada abad pengetahuan (abad 21) diperlukan sumber daya manusia berkualitas tinggi yakni memiliki kemampuan bekerja sama dan berpikir tinggi (berpikir kritis dan kreatif). Menurut Bloom berpikir tinggi mencakup analisis, dan evaluasi. Dalam perkembangannya, taksonomi Bloom mengalami modifikasi dalam strukturnya sebagai hasil revisi Anderson \& Karthwohl yakni analisis, evaluasi, dan mencipta (Fajriyah, 2018).

Adapun dalam pembelajaran PAI di SMA Negeri II Kota Pasuruan padas kelas $\mathrm{X}$ menggunakan metode yang bervariasi sesuai dengan dipaparkan oleh bapak Gathot bahwa guru PAl diberi kebebasan dalam mengeksplorasi pembelajaran namun tetap disesuaikan dengan perencanaan yang ada di RPP (wawancara kepala skeolah, Suyono, 2021). Berdasarkan wawancara dengansalah satu guru PAl Ibu Durroh memberikan penjelasan bahwa metode yang pembelajaran yang dipilih oleh guru PAI merupakan metode yang kreatif inovatif dan menyenangkan contoh penggunaan metode ceramah dikombinasikan dengan metode PBL (Problem Base learning) dengan tujuan agar siswa dapat berfikir tinggi dalam pemecahan masalah melalui PBL (wawancara guru Solikhah, 2021) Sebagaimana yang dikatakan Danang Satria bahwa kegiatan pembelajaran PAl yang paling menarik adalah ketika mendiskusikan materi pelajaran yang ditugaskan oleh guru dalam memecahkan permasalahan yaitu dengan cara guru memberikan satu permasalahan, lalu siswa mendiskusikan dengan kelompoknya kemudian didalam kelompok mencari pemecahan masalah dan hasil dide setiap kelompok kemudian didiskuiskan dikelas. Pembelajaran dengan menggunakan metode ini sangat menyenangkan dan penuh dengan tantangan (Wawancara Satria, 2021). Senada dengan pendapat guru PAI lainnya, ibu Fatim menjelaskan bahwa siswa sangat antusias mengikuti pelajaran PAl dengan model PBL ini, karena dapat memicu siswa untuk berfikir tinggi dalam pemecahan masalah, hal 
ini dapat melatih kognitif siswa untuk terbiasa berfikir kritis ( wawancara guru zahroh, 2021).

Dari paparan di atas, penulis dapat memberikan kesimpulan bahwa saat penjelasan materi PAI berlangsung siswa dituntut untuk berifikir tinggi yakni menganalisis masalah yang diberikan oleh guru ketika diberi tugas untuk mencari pemecahan masalah di setiap kelompoknya. Hal ini sama seperti yang dikatakan Anderson dan Krathwohl mengategorikan kemampuan proses menganalisis (analyzing), mengevaluasi (evaluating), dan mencipta (creating) termasuk berpikir tingkat tinggi. Menganalisis adalah kemampuan menguraikan sesuatu ke dalam bagian-bagian yang lebih kecil sehingga diperoleh makna yang lebih dalam. Menganalisis dalam taksonomi Bloom yang direvisi ini juga termasuk kemampuan mengorganisir dan menghubungkan antar bagian sehingga diperoleh makna yang lebih komprehensif (Setiawati, dkk, 2019).

Selain siswa memiliki kemampuan dalam menginterpretasikan pemecahan masalah, siswa dituntut harus aktif berpartisipasi dalam proses pembelajaran, hal inilah yang dapat mendorong guru PAI memiliki upaya untuk memberikan rangsangan pada siswa agar supaya siswa turut aktif dalam proses pembelajaran. Guru bisa memberikan kesempatan seluas-luasnya kepada siswa untuk bertanya ketika proses pembelajaran. Seperti yang penulis tanyakan kepada Aisyah bahwa ia mengatakan merasa senang dengan penjelasan guru yang sangat mendalam dan detail ketika ia bertanya kepada guru PAI sehingga ia merasa dapat menguasai ilmu yang mendalam dari hasil jawaban guru yang sangat jelas dan detail itu (wawancara andini, 2021). Begitu juga yang disampaikan oleh Deco bahwa ia merasa memiliki hubungan interaksi yang baik dengan guru PAI ketika Pembelajaran berlangsung karena diberikan kesempatan bertanya oleh guru mengenai materi yang belum ia fahami sehingga ia merasa benar- benar paham terhadap materi yang dipelajarari saat itu (wawancara Syahputra, 2021).

Pendapat lain disampaikan oleh llham tentang guru yang menanyakan kepada siswanya satu persatu dalam proses pembelajaran, hal ini dapat menumbuhkan motivasi belajar bagi siswa karena siswa terdorong dalam memepelajari dan memahami pelajaran tersebut, siswa berupaya dengan belajar sungguh-sungguh dengan harapan siswa mampu memperisiapkan jawaban jika sewaktu-waktu mendapatkan pertanyaan dari guru (wawancara Pratama, 2021). Seperti pernyaatan Afif bahwa siswa diperbolehkan bertanya bukan hanya tentang materi pelajaran tetapi juga tentang materi diluar pelajaran sehingga Danial merasa tertarik untuk bertanya karena dapat menambah wawasan dan pengetahuan secara umum (wawancara Yanuarta, 2021). Siswa bernama Nofita mengungkapkan bahwa metode pembelajaran yang digunakan oleh guru PAI sangat menyenangkan sehingga menjadikan wulan senang mengukuti pelajaran PAI (wawancara Sari, 2021).

Berdasarkan paparan di atas, penulis dapat menyimpulkan bahwa guru yangkreatif dalam pembelajaran bukanlah hanya guru yang pandai menyampaikan 
materi dengan baik melainkan guru yang mampu memberikan kesempatan seluas-luasnya kepada siswanya untuk mengemukakan pendapat dan argumentasinya karena hal demikian dapat melatih siswa berfikir aktif dan kritis. Hal ini sejalan dengan teori yang dikutip oleh Ridwan Abdullah Sani mengenai karakteristik pembelajaran dengan pendekatan Higher Order Thinking Skills (HOTS) yakni “Merangsang siswa untuk berani mengajukan pendapat atau pertanyaan. Guru dapat melatih siswa untuk membuat pertanyaan atau pernyataan setelah menampilkan sebuah fenomena yang menarik misalnya melalui video, demonstrasi, atau cara lainnya. Guru harus melatih kepercayaan diri siswa agar yakin pada dirinya dalam penguasaan pengetahuan dan berpikir" (Sani,2019).

Upaya guru PAI dalam melatih argumentasi siswa dengan membagi siswa menjadi beberapa kelompok, kemudian guru memberikan satu permasalahan dan setiap kelompok diharuskan memikirkan ide-ide solusi yang ditawarkan dalam pemecahan masalah, kemudian ide-ide tersebut didiskusikan dan bertukar ide dengan kelompok lain sehinggan akan muncul pro dan kontra, dan disinilah secara sengaja akan tumbuh pikiran kritis karena guru akan meminta argumen-argumen dari setiap ide siswa beserta alasan-alasan logisnya. Cara inilah yang dilakukan oleh guru PAI dalam mengasah skill berfikir analitis siswa melalui penggunaan metode yang dipilih oleh guru PAI (wawancara guru Solikhah, 2021).

Dari paparan di atas bahwa cara ini dapat melatih siswa berfikir aktif dan berfikir kritis. Dan pada tahap ini siswa dapat mengevaluasi hasil berfikir aktif dan kritisnya. Seperti yang dikatakan oleh Elaine bahwa berpikir kritis adalah sebuah kemampuan untuk mengatakan sesuatu dengan percaya diri, memungkinkan siswa untuk menemukan kebenaran dari suatu informasi dan sebuah proses terorganisir yang memungkinkan siswa mengevaluasibukti, asumsi, logika dan bahasa yang mendasari pernyataan orang lain terjadi dalam berpikir kritis (Nofikasari, 2009).

Selain penggunaan metode yang tepat, pelaksanaan pembelajaran PAI juga disertai dengan penggunaan sumber belajar dan media pembelajaran yang memadai. Seperti yang diungkapkan oleh Firda tentang sumber belajar yang digunakan adalah lebih sering menggunakan buku (wawancara Akmalia, 2021) namun terkadang juga menggunakan sumber dari internet, sering juga guru memanfaatkan Powerpoint dalam menyampaikan materi menurut penjelasan Yogi Fahrezi (wawancara Fahrezi, 2021).

Dari paparan di atas, penulis dapat menyimpulkan bahwa guru menggunakan sumber yang lebih mengutamakan pada penggunaan buku mata pelajaran namun saat pelaksanaan diskusi untuk menambah fikir siswa, ia juga membutuhkan sumber belajar dari lainnya, missal sumber dari internet dsb. Abdullah sani memaparkan tentang karakteristik pembelajaran HOTS adalah aktifitas belajar siswa dapat mencari dan memanfaatkan informasi belajar dari berbagai macam sumber baik dari buku maupun lainnya karena hal ini dapat 
memberi akomodasi perbedaan karakteristik gaya belajar siswa, kemampuan siswa, kebutuhan, minat belajar, keingintahuan, dan kemampuan awal yang dimiliki masing-masing siswa (Sani, 2019).

Untuk mengenai media pembelajaran yang sering dimanfaatkan dalam pembelajaran PAI ini, seperti yang dijelaskan oleh ibu Durroh selaku guru PAI kelas $\mathrm{X}$ mengatakan bahwa penggunaan media disesuaikan dengan kebutuhan materi yang dibahas dan disesuaikan dengan metode yang dipakai, missal hari ini kita akan demontrasi tentang pelaksanaan haji dan umroh, maka media yang digunakan adalahminiature ka'bah yang didatangkan ke halaman sekolah, atau terkadang kita melakukan kegiatan ini studi outdoor ke tempat wisata religi yang memiliki miniature ka'bah (wawancara guru Solikhah, 2021). Senada dengan penjelasan pak Gathot bahwa penggunaan media dalam pembelajaran PAI disesuaikan dengan kebutuhan masing-masing, missal membutuhkan miniature ka'bah maka dari pihak sekolah memfasilitasi dengan penyewaan miniature ka'bah yang didatngkan ke sekolah atau pernah juga sekolah memberi fasilitas kendaraan untuk studi outdoor bagi siswa yang akan melakukan praktik diluar sekolah (wawancara kepala sekolah suyono, 2021).

Tegar Satria juga memberikan tambahan penjelasan terkait penggunaan media pembelajaran yang dipakai dalam pembelajaran PAI, pernah menggunakan media miniaturm ka'bah yang didatangkan ke sekolah, pernah juga kita mengikuti studi outdoor ke tempat wisata religi untuk melaksanakan demontrasi tentang materi haji dan umroh (wawancara Yudhistira, 2021). Senada dengan pemaparan Elisa dalam kegiatan diskusi terkadang guru memanfaatkan media proyektor untuk menampilkan tema-temadiskusi (wawancara Elisa, 2021).

Dari penjelasan di atas, peneliti dapat menyimpulkan bahwa dalam pemanfaatan media pembelajara guru PAI sudah memanfaatkan media visual berupaminiature ka'bah, media Powerpoint dsb. Seperti penjelasan Wina Sanjaya bahwa Media pembelajaran sangat penting dalam proses pembelajaran karena guru dapat menyampaikan materi kepada siswa menjadi lebih bermakna. Guru tidak hanya menyampaikan materi berupa kata-kata dengan ceramah tetapi dapat membawa siswa untuk memahami secara nyata materi yang di sampaikan tersebut (Sanjaya, 2014). Berikut alur Implementasi Pendekatan HOTS dalam Pembelajaran PAI: 


\section{LANGKAH-LANGKAH IMPLEMENTASI PENDEKATAN HOTS DALAM PEMBELAJARAN PAI}

\section{Pendahuluan (10 Menit) \\ 1. Guru Membuka Pembalajaran \\ 2. Guru melakukan perkenalan \\ 3. Guru menyampaikan pengantar, tujuan pembelajaran \\ 4. Menyapaikan rencana pelaksaanaan pembelajaran PAI pada pertemuan ini}

\section{Penguatan/Refleksi (10 Menit)}

1. Guru Menarik Kesimpulan Materi pertemuan ini

2. Guru melakukan penguatan dengan cara menanyakan tentang tingkat pemahaman siswa pada materi pertemuan ini

3. Guru Menutup Pertemuan
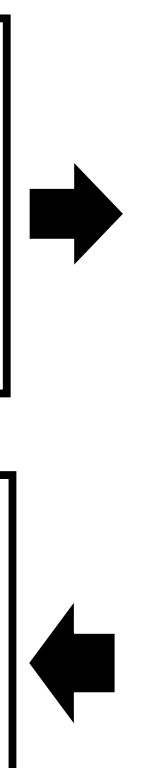

\section{Kegiatan Inti (60 Menit)}

1. Guru Siswa Menjadi 5 Kelompok

2. Guru Menjelaskan Materi menggunakan Metode Ceramah Yang dikombinasikan dengan PBL

3. Setiap kelompok diberikan 1 topik/masalah yang akan didiskusikan dalam kelompok

4. Siswa melalakukan diskusi dengan kelompok masing-masing

5. Perwakilan dari kelompok memaparkan hasil diskusinya di depan kelas

6. Guru membuka sesi tanya jawab kemudian siswa dipersilahkan bertanya dan menambahi jawaban dari pertanyaan teman kelasnya

\section{Penilaian Pembelajaran PAI dengan Pendekatan HOTS}

Setiap tahapan pembelajaran pasti diakhiri dengan tahapan evaluasi. Disini evaluasi merupakan sebagai alat ukur dari hasil pembelajaran yang telah dilakukan. Proses penilaian tidak terjadi secara tiba-tiba penilaian juga harus sudah dibuat ketikan membuat rencana pembelajaran. jadi disini penilaian sangat berhubungan erat dengan proses pembelajaran yang telah didesain oleh guru dan dilaksanakan bersama oleh peserta didik. Jadi disini guru harus mengerti antara pembelajaran yang sudah dilaksanakan dengan evluasi (penilaian) yang dilakukan itu sesuai ( Nugroho, 2018).

Penilaian HOTS mengharuskan pembelajaran untuk memanfaatkan informasi dan gagasan dengan cara mengubah makna dan implikasinya. Hal ini seperti ketika pembelajaran menggabungkan fakta dan gagasan kemudian menyintesis, mengguneralisasi, menjelaskan, memberi hipotesis, atau menyilmpulkan (Mulyaningsih, 2018). Oleh karena itu dalam pembelajaran peserta didik harus bisa memeahami, menafsirkan, menganalisis, serta menginterprestasi informasi yang diterima. HOTS juga mengajarkan peserta didik untuk berpikir kritis dalam mengevaluasi informasi, membuat simpulan, serta membuat generalisasi. Dalam Taksonomi Bloom revisi, HOTS merupakan kemampuan kognitif pada tingkat penerapan, analisis, evaluasi, dan inovasi.

Setiap tahapan pembelajaran pasti diakhiri dengan tahapan evaluasi. Dan setiap orang yang melakukan suatu kegiatan pembelajaran diakhiri dengan 
tahapan evaluasi. Peneliti pun menanyakan pada salah satu siswa tentang materi yang sudah dipelajarinya, hal ini diungkapkan oleh Putra memaparkan bahwa ia sangat memahami materi PAl yang sudah ia pelajari. Pendapat yang senada diungkapkan oleh Nadif bahwa ia sangat memahami materi yang dijelaskan oleh guru PAI karena penjelasannya sangant detail dan mendalam dan meluas diambil dari berbagai sumber tidak hanya dari buku pelajaran (wawancara putra, 2021). Begitu juga penjelasan dari siswa lainnya juga mengatakan bahwa mereka cukup faham dengan materi PAI yang ia pelajari.

Berdasarkan dari hasil interview di atas, peneliti dapat memberikan kesimpulan bahwa pembelajaran PAI dengan menggunakan Pendekatan HOTS ini bisa dikatakan berjalan efektif Karena telah mampu menjadikan siswa mudah memahami materi pelajaran dan terjalin komunikasi yang baik antara guru dan siswa. Seperti yang dipaparkan Miftah dalam Jurnal Teknologi Pendidikan bahwa Manfaat komunikasi yang efektif dalam pembelajaran, antara lain: memudahkan siswa memahami materi yang disampaikan guru dan melaksanakannya, memberikan kontribusi untuk keberhasilan belajar siswa, menciptakan lingkungan belajar yang kondusif dan interaktif, dan dapat meningkatkan motivasi serta minat belajar siswa (Miftah, 2008).

Selanjutnya setelah peneliti menanyakan tentang hasil belajar PAI dengan pendekatan HOTS, kemudian meneliti menenayakan kepada kepala sekolah tentang perubahan sikap siswa setelah mempelajarai PAl dengan menggunakan pendekatan HOTS. Seperti yang diungkapkan oleh pak Gathot bahwa pembelajaran dengan menggunakan pendekatan HOTS ini dapat melatih siswa untuk lebih aktif, kritis sehinggan kreatifitas siswa terus meningkat. Begitu juga dengan guru PAl nya, semakin terlihat semangat menambah mengasah kemampuannya supaya dapat mendesain pembelajaran PAl terus meningkat dan semakin kreatif (wawancara kepala sekolah suyono, 2021).

Perubahan lain yang dilakukan siswa bernama Alivia mengatakan bahwa ia merupakan siswa yang cukup pandai dan suka tidak peduli sama temantemannya. Namun setelah saya mempelajarai kompetisi yang baik dalam belajar, saya punya keinginan untuk mengajak teman-teman lain belajar bersama dan bersaing secara baik dan saya selalu berusahan untuk tetap menjadi siswa yang unggul dan lebih baiklagi ke depannya (wawancara Maritza, 2021).

Peneliti memberikan kesimpulan bahwa siswa sudah mencoba melakukan sesuatu yang baru dalam kegiatan sehari-hari di sekolah dan siswa berusaha mengajak teman-temannya dalam hal menerapkan materi berkompetisi secara baik dalam pembelajaran, sehingga siswa dapat bersaing secara baik untuk menjadi siswa yang unggul dan berprestasi. Tahapan ini merupakan bagian dari level mengkreasi/ mencipta dalam berfikir tingkat tinggi, seperti berusahan melakukan hal-hal baru yang positif bahkan menjdawalkan kegiatan tersebut. Senada dengan ungkapan Anderson dan Karthwohl 
menjelasakan tentang mencipta dapat diartikan sebagai menggeneralisasikan ide baru, bentuk produk, atau cara pandang tehadap suatu kejadian. ${ }^{1}$ (Purnomo, 2019

Tentang evaluasi yang dilakukan oleh guru PAI adalah dilakukan di akhir pembelajaran seperti yang dijelaskan oleh ibu Fatim bahwa biasanya ia memberikan Post-Test secara lisan kepada siswa dengan cara menanyakan satu persatu kepada siswa tentang materi yang sudah dipelajari, terkadang guru PAI juag memberikan ujian Tulis berbentuk Quiz di akhir Tema biasanya setelah tiga tau empat pertemuan.Sedangkan mengenai evaluasi secara keseluruhan guru PAI juga melakukan Ujian Tengah Semester di pertengahan Semester, begitu juga dengan Ujian Akhir Sekolah dilakukan di akhir semester dengan catatan ujian ini mengacu pada panduan Dinas (wawancara guru Zahroh, 2021).

Maka berdasarkan paparan di atas peneliti dapat menyimpulkan bahwa guru PAI sudah melakukan evaluasi setiap akhir pelajaran, setelah selesai satu tema begitu juga sudah melakukan Ujian di pertengahan dan akhir semester untuk mengetahui tingkat keberhasilan belajar siswa. Sedangkan pembahasan tentang Evaluasi yang sudah dilakukan oleh guru PAI berupa Lisan mau Tulis ini merupakan sesuai dengan Peraturan Menteri Pendidikan Nasional (Permen Diknas) Nomor 20 Tahun 2007 tentang Standar Penilaian Pendidikan Penilaian hasil belajar oleh pendidik menggunakan berbagai teknik. ${ }^{2}$ (lampiran permendiknas, 2007)

Bentuk Penilaian Pembelajaran PAI dengan Menggunakan Pendekatan HOTS

\begin{tabular}{clll}
\hline No & Bentuk Penilaian & Aspek yang dinilai & \multicolumn{1}{c}{ Laporan Peneliain } \\
\hline 1. & Penilaian Harian & Sikap & Predikat dan Deskripsi \\
\hline 2. & $\begin{array}{l}\text { Penilain Tengah } \\
\text { Semester }\end{array}$ & Pengetahuan & Angka, Predikat dan Deskripsi \\
\hline 3. & $\begin{array}{l}\text { Penilaian Akhir } \\
\text { Semester }\end{array}$ & Keterampilan & Angka, Predikat dan Deskripsi \\
\end{tabular}

1 Pajar Purnomo, Penilaian Pembelajaran HOTS (Higher Order Thinking Skills), (Semarang:Candradimuka Press, 2019), h. 47.

2 Lampiran Peraturan Menteri Pendidikan Nasional (Permendiknas) Nomor 20 Tahun 2007 tentang Standar Penilaian Pendidikan) 


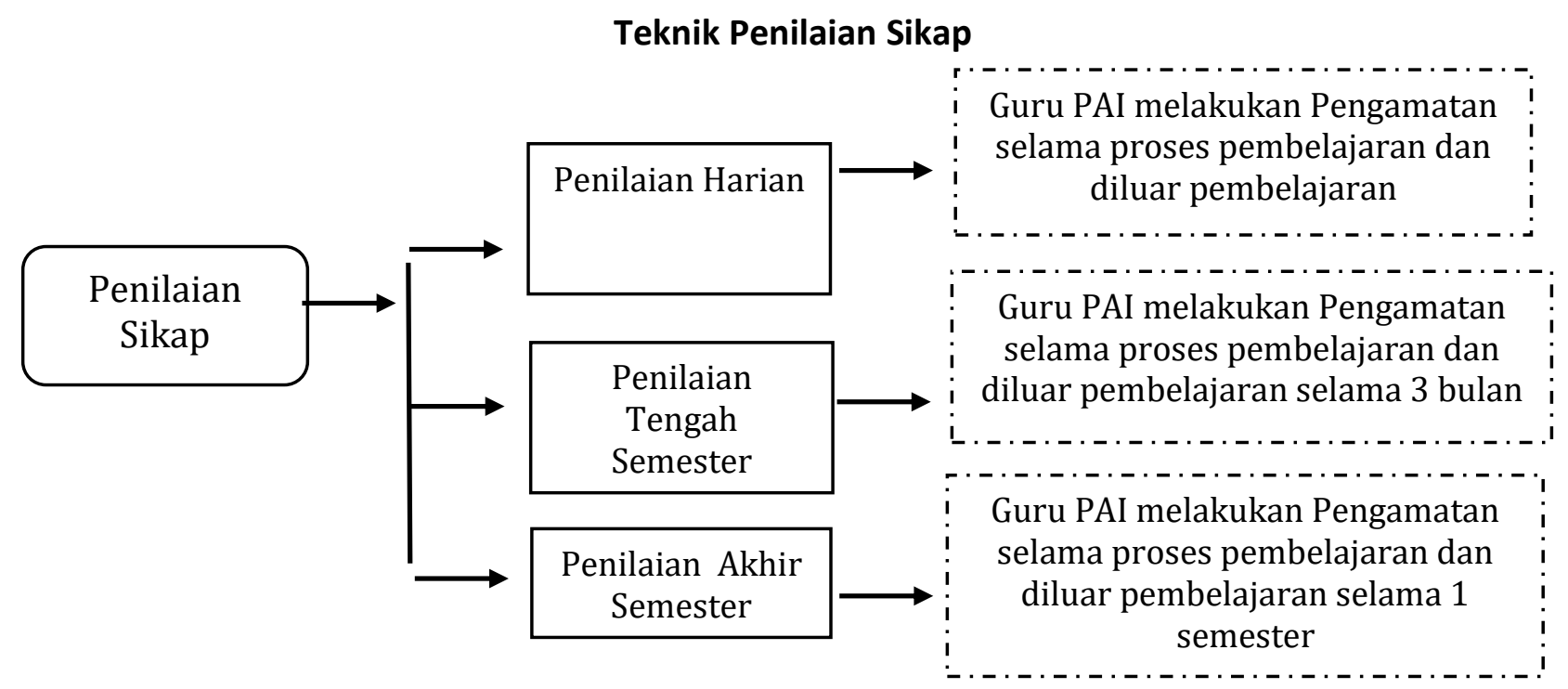

Lembar Penilaian Diri menggunakan daftar cek (checklist) pada waktu kegiatan kelompok.

Nama

Kelas/Semester ..

Petunjuk:

1. Bacalah baik-baik setiap pernyataan dan berilah tanda $\vee$ pada kolom yang sesuai dengan keadaan dirimu yang sebenarnya.

2. Serahkan kembali format yang sudah kamu isi kepada bapak/ibu guru.

\begin{tabular}{llll}
\hline No & \multicolumn{1}{c}{ Pernyataan } & Ya & Tidak \\
\hline 1. & Mengusulkan ide kepada kelompok & \\
\hline 2. & Sibuk mengerjakan tugas saya sendiri & \\
\hline 3. & Tidak berani bertanyaan karena malu takut ditertawakan & \\
\hline 4. & Menertawakan pendapat teman & \\
\hline 5. & Aktif mengajukan pertanyaan dengan sopan \\
\hline 6. & Melaksanakan kesepakatan kelompok, meskipun tidak sesuai & \\
& dengan pendapat saya
\end{tabular}

\section{Instrumen penilaian (lembar pengamatan) antarteman (peer assessment) menggunakan daftar cek (checklist) pada waktu kerja kelompok.}

Petunjuk

1. Amati perilaku 2 orang temanmu selama mengikuti kegiatan kelompok.

2. Isilah kolom yang tersedia dengan tanda cek $(\mathrm{V})$ jika temanmu menunjukkan perilaku yang sesuai dengan pernyataan untuk indikator yang kamu amati atau tanda strip (-) jika temanmu tidak menunjukkan perilaku tersebut.

3. Serahkan hasil pengamatan kepada bapak/ibu guru. 
Nama Teman : 1

2.

Nama Penilai

Kelas/Semester

\begin{tabular}{lll}
\hline No & Pertanyaan/indikator pengamatan & Teman 1 \\
\hline 1. & $\begin{array}{l}\text { Teman saya mengajukan pertanyaan } \\
\text { dengan sopan }\end{array}$ \\
\hline 2. & $\begin{array}{l}\text { Teman saya mengerjakan kegiatan } \\
\text { sesuai pembagian tugas dalam } \\
\text { kelompok }\end{array}$ \\
\hline 3. & $\begin{array}{l}\text { Teman saya mengemukakan ide } \\
\text { untuk menyelesaikan } \\
\text { Masalah }\end{array}$ \\
\hline 4. & $\begin{array}{l}\text { Teman saya memaksa kelompok } \\
\text { untuk menerima usulnya }\end{array}$ \\
\hline 5. & $\begin{array}{l}\text { Teman saya menyela pembicaraan } \\
\text { teman kelompok }\end{array}$ \\
\hline 6. & $\begin{array}{l}\text { Teman saya menjawab pertanyaan } \\
\text { yang diajukan teman lain }\end{array}$ \\
\hline 7. & $\begin{array}{l}\text { Teman saya menertawakan } \\
\text { pendapat teman yang aneh }\end{array}$ \\
\hline 8. & $\begin{array}{l}\text { Teman saya melaksanakan } \\
\text { kesepakatan kelompok meskipun } \\
\text { tidak sesuai dengan pendapatnya }\end{array}$
\end{tabular}

Skema Penilaian Pengetahuan

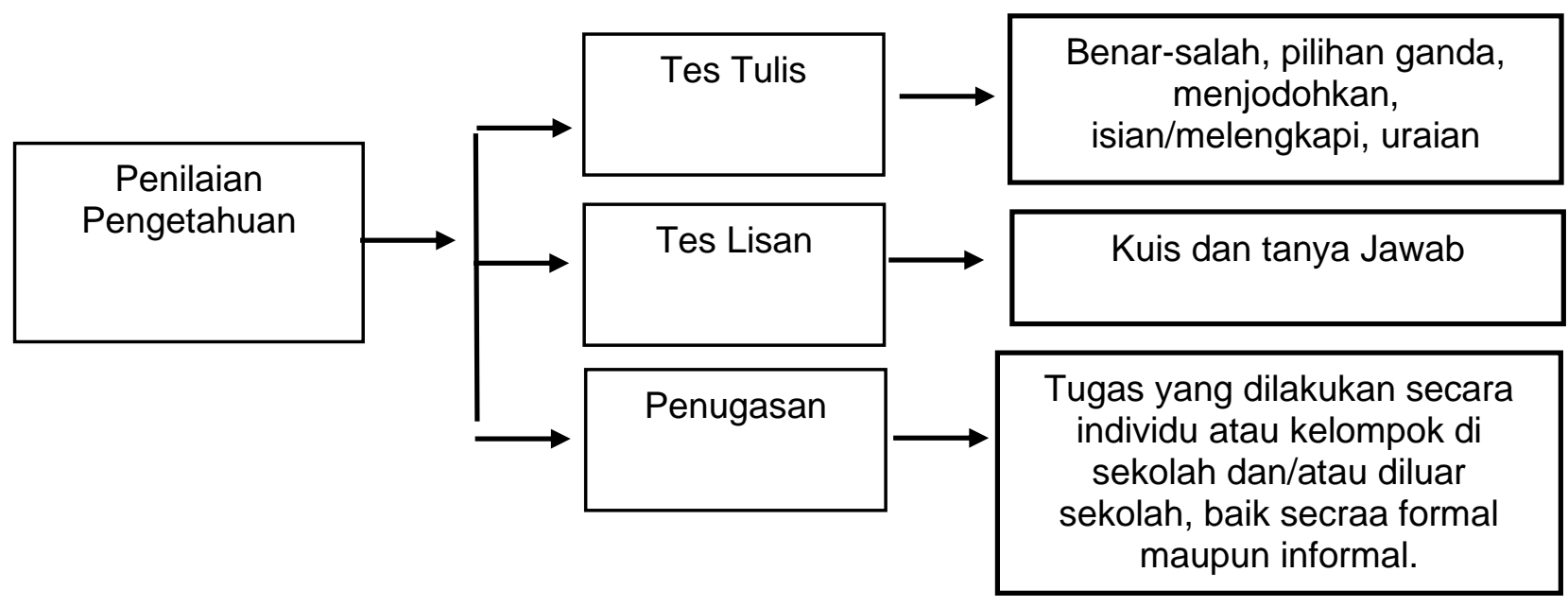




\section{Skema Penilaian Keterampilan}

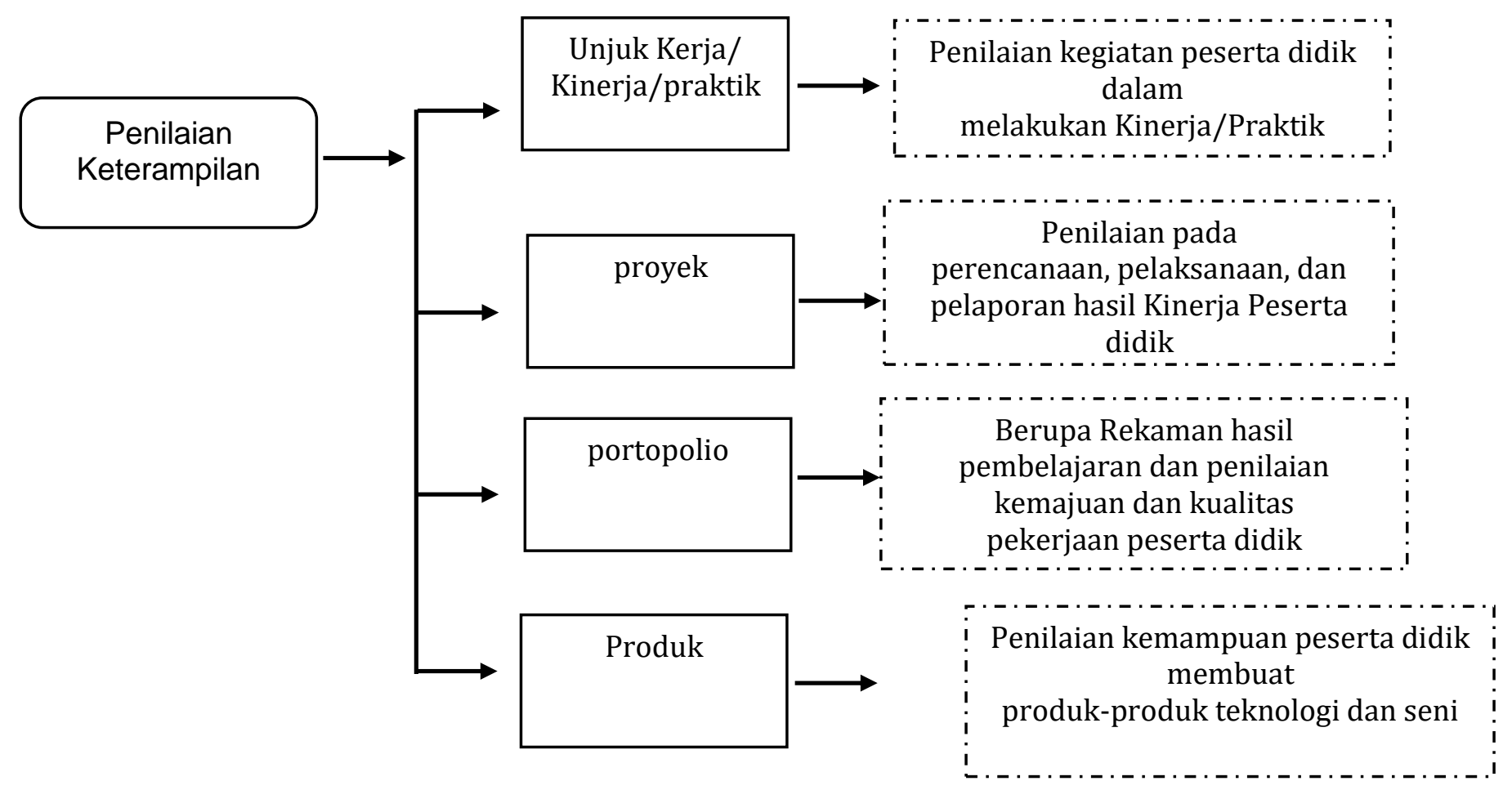

\section{KESIMPULAN}

Berdasarkan pemaparan di atas, penulis memberikan kesimpulan bahwa impelementasi Pendekatan HOTS ini diimplementasikan dalam tiga tahapan. Pertama, dalam tahap penyusunan perencanaan pembelajaran dengan menggunakan pendekatan HOTS yaitu dengan mendesain RPP oleh guru PAI, tahap kedua yaitu tahap pelaksanaan pembelajaran PAI dengan menggunakan Pendekatan HOTS, tahap ketiga yaitu tahap Evaluasi Pembelajar PAI dengan menggunakan Instrumen Penilaian Pembelajaran PAI berbasis HOTS.

Dalam Implementasi pendekatan HOTS dalam pembelajaran PAI dapat dikatakan bahwa siswa dalam tahap pembelajaran sudah mampu mengaktualisasikan teori Taksonomi Bloom yaitu pada tahap level menganalisis, mengevaluasi, mengkreasi. Indikator siswa sudah sampai pada Tingkatan Menganalisis yaitu saat siswa mampu menyelesaikan tugas berkelompok dengan mencari ide penyelesaian masalah dari tugas yang guru berikan melalui tayangan di Power point, lalu setiap ide yang ditawarkan oleh tiap kelompok didiskusikan dan bertukar ide dengan kelompok lain. Dari sini terlihat dengan jelas bahwa siswa sudah mampu berfikir tinggi dan kritis dan mampu memecahkan masalah dalam kelompok masing-masing.

Sedangkan pada tingkatan level mengevaluasi tampak ketika guru dengan 
sengaja memberikan contoh perilaku yang tidak tepat, misal tentang perilaku melanggar tatib sekolah, perilaku saling menjatuh teman, tujuannya untuk merangsang siswa supaya berfikir dan dapat menyapaikan argumentasinya tentang perilaku yang siswa lihat didepannya. Selanjutnya pada tahapan level mengkreasi dalam pembelajaran dapat dilihat ketika guru PAI melakukan evaluasi tentang perubahan siswa setelah mengikuti kegiatan pembelajaran, seperti melihat siswa yang antusias membuat jadwal kegiatan sehari-hari dengan tujuan bisa bersikap disiplin waktu dimulai dari diri sendiri dan itu dilakukan siswa penuh dengan kesadaran. Evaluasi lainnya dapat dilakukan oleh guru PAI dengan cara memberikan beberapa pertanyaan secara lisan kepada siswa di akhir pembelajaran untuk melihat keberhasilan belajar siswa, di akhir tema bisa dilakukan Quiz baik secara lisan maupun tulisan yang mana dalam pembuatan soalnya dapat mengacu pada indicator evaluasi HOTS walaupun pada tingkatan yang masih disempurnakan.

\section{DAFTAR PUSTAKA}

Arikunto, Suharsimi. 2002. Prosedur Penelitian: Suatu Pendekatan Praktik. Jakarta: RinekaCipta.

Direktorrat Jenderal Guru dan Tenaga Kependidikan. Guru Penggerak Indonesia Maju,wujudkan Sumber Daya Manusia yang Unggul. https://p4tkbmti.kemdikbud.go.id/main/2019/12/04/mendikbud-gurupenggerak-indonesia-maju-wujudkan-sdm-yang-unggul/. 2019

Fajriyah, Khusnul dan Agustini, Ferina. 2018. Analisis Ketrampilan Berpikir Tingkat Tinggi Siswa SD Pilot Project Kurikulum 2013 Kota Semarang", Elementary School 5, 1, Januari 2018.

FI, Thufail. Peneliti LIPI: Jepang Society 5.0 Akan Gagal Seperti Cool Japan. https://www.aminef.or.id/peneliti-lipi-jepang-society-5-0-akan-gagalseperti-cool-japan/. Published 2011

Hayon, Vinsensia H.B. dan Wariani, Theresia. dkk, 2017. Pengaruh Kemampuan BerpikirTingkat Tinggi (High Order Thingking) Terhadap Hasil Belajar Kimia Materi Pokok Laju Reaksi Mahasiswa Semester I Program Studi Pendidikan Kimia FKIPUnwira Kupang Tahun Akademik 2016/2017. Kupang: TP.

Kunandar. 2011. Guru Profesional (Implementasi Kurikulum Tingkat Satuan Pendidikan dan Sukses dalam Sertifikasi Guru). Jakarta: Raja Grafindo Persada.

Lampiran Peraturan Menteri Pendidikan Nasional (Permendiknas) Nomor 20 Tahun2007 tentang Standar Penilaian Pendidikan

Majid, Abdul. 2017. Perencanaan Pembelajaran. Bandung: Rosdakarya.

Miftah, M. 2008. Strategi Komunikasi Efektif dalam Pembelajaran, Jurnal Teknodik Vol. 12 No. 2, Desember 2008.

Moloeng, Lexy J. 2002. Metodologi Penelitian Kualitatif. Bandung: PT Remaja Rosdakarya.

Mulyaningsih, Indra. 2018. Pengembangan Pembelajaran bad 21 Bermuatan HOTS (HighOrder Thingking Sklls). Proposal: IAIN Syekh Nurjati Cirebon. 
Novikasari, Ifada. 2009. Pengembangan Kemampuan Berpikir Kritis Siswa melalui Pembelajaran Matematika Open-ended di Sekolah Dasar, dalam Jurnal PemikiranAlternatif Kependidikan Vol. 14, No. 2,Mei-Ags 2009.

Nugroho, Arifin. 2018. HOTS (Kemampuan Berpikir Tingkat Tinggi: Konsep Pembelajaran Penilaian dan soal-soal). Jakarta: Gramedia Widiasarana Indonesia.

Purnomo, Pajar. 2019. Penilaian Pembelajaran HOTS (Higher Order Thinking Skills). Semarang: Candradimuka Press.

Rofiah, Emi. Dkk. 2013. "Penyusunan Instrumen Tes Kemampuan Berpikir Kritis TingkatTinggi Fisika pada Siswa SMP", dalam jurnal pendidikan fisika, Vol. 1, No. 2.

Sani, Ridwan Abdullah. 2019. Pembelajaran Berbasis HOTS. Tanggerang: Tira Smart.

Sanjaya, Wina. 2014. Media Komunikasi Pembelajaran. Jakarta: Kencana Prenada Media Group.

Setiawati, Wiwik. Dkk. 2019. Buku penilaian berorientasi higher order thinking skills. Jakarta: Direktorat Jenderal Guru dan Tenaga Kependidikan Kementerian Pendidikan dan Kebudayaan.

Sofyan, Fuaddilah Ali. 2019. Implementasi HOTS Pada Kurikulum 2013", Jurnal Inventa, 1 (Maret 2019).

Sugiyono. 2013. Metode Penelitian Pendidikan Pendekatan Kauntitatif, kualitatif dan $R \& D$. Bandung: Alfabeta.

Susanto, Edi dan Rahmawati, Heri. 2016. Perangkat Pembelajaran Matematika BercirikanUntuk Mengembangkan HOTS Siswa SMA", Jurnal Rises Pendidikan Matematika,2, November 2016.

Uno, Hamzah B. 2016. Perencanaan Pembelajaran. Jakarta: Bumi Aksara. 